\title{
Etiology, management, and survival of acute mechanical bowel obstruction: Five-year results of a training and research hospital in Turkey
}

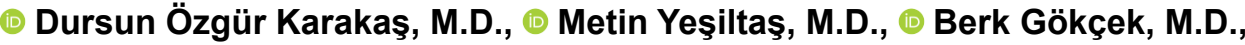 \\ (1) Seracettin Eğin, M.D., (- Semih Hot, M.D.
}

Department of General Surgery, Okmeydanı Training and Research Hospital, İstanbul-Turkey

\begin{abstract}
BACKGROUND: Acute mechanical bowel obstruction (AMBO) is still a major surgical problem for emergency departments. The aim of this study was to evaluate AMBO in terms of etiology, management, and survival.

METHODS: Data of the age, sex, etiology, management, and survival of patients who were hospitalized for bowel obstruction between January 2014 and December 2018 were evaluated retrospectively. Adhesions, tumors, hernias and peritoneal carcinomatosis were evaluated in detail.

RESULTS: A total of 735 patients were included in the study. The obstruction was located in the small bowel (AMSBO) in $60 \%$ and in the large bowel (AMLBO) in $40 \%$. The mean patient age was $59.9 \pm 16.02$ years and $52.9 \%$ of the patients were male. Adhesion, tumor, and hernia were the most common etiologies of the overall AMBO group ( $43.3 \%, 26.2 \%$, and $6 \%$, respectively). The most common etiology for AMSBO was an adhesion (69.3\%), while it was a tumor for AMLBO cases (6I.6\%). The most common management of AMBO patients was a conservative approach (53.2\%; adhesions: $76.7 \%$ ). Surgical palliation was performed in $24.9 \%$ (peritoneal carcinomatosis: $65.7 \%$ ), and resection was performed in $21.9 \%$ (volvulus: $61.9 \%$ ). The mortality rate in the group was $8.6 \%$. The most common etiology was colorectal surgery (5I.4\%) for adhesions, colorectal cancer (93.8\%) for tumors, and incisional hernia (47.7\%) in cases of hernia-related AMBO.
\end{abstract}

CONCLUSION: Adhesions, tumors, and hernias are the most common etiologies of AMBO. The incidence of femoral/inguinal hernia have decreased while that of incisional hernia has increased, and it was further observed that peritoneal carcinomatosis has now become as common as hernia as a cause.

Keywords: Adhesion; acute colonic pseudo-obstruction; bowel obstruction; hernia; paralytic ileus; tumor.

\section{INTRODUCTION}

Acute mechanical bowel obstruction (AMBO) is still one of the major surgical problems encountered in emergency departments. AMBO constitutes $3 \%$ of all emergency admissions and $15 \%$ of acute abdominal pain cases. AMBO is an important cause of mortality as well as costs, as it may involve a long hospital stay, readmissions, and reoperations. ${ }^{[1]}$ AMBO is described as local blockage of intestinal content transit for reasons that may be intramural (e.g., invagination, bezoar, gallstone, etc.), mural (e.g., cancer, inflammation, congenital cause, etc.), or extramural (e.g., hernia, adhesion, etc.). AMBO is described as small (AMSBO) or large (AMLBO) according to the level of the bowel obstruction, and complete or incomplete obstruction according to the discharge of gas. ${ }^{[2]}$

AMBO is observed in the small bowel in $75 \%$ to $80 \%$ of cases and in the large bowel in $20 \%$ to $25 \% .^{[3]}$ The etiology of AMBO varies according to considerations such as age, development of the country of occurrence, and the level of the obstruc-

Cite this article as: Karakaş DÖ, Yeşiltaş M, Gökçek M, Eğin S, Hot S. Etiology, management, and survival of acute mechanical bowel obstruction: Five-year results of a training and research hospital in Turkey. Ulus Travma Acil Cerrahi Derg 2019;25:268-280.

Address for correspondence: Dursun Özgür Karakaş, M.D.

Okmeydanı Eğitim ve Araştırma Hastanesi, Genel Cerrahi Kliniği, İstanbul, Turkey

Tel: +90 212 - 3145555 E-mail: drdok1978@hotmail.com

Ulus Travma Acil Cerrahi Derg 2019;25(3):268-280 DOI: 10.14744/tjtes.2019.44834 Submitted: 23.01.2019 Accepted: 03.05.2019 Online: I5.05.2019 Copyright 2019 Turkish Association of Trauma and Emergency Surgery 
tion in the bowel. A hernia is still a common cause of AMBO in developing countries, while postoperative adhesions are the most common cause in developed countries as a result of the increase in surgical procedures. Postoperative adhesions have been reported to be the most common cause of small bowel obstruction and colorectal cancers have similarly been described as the most common cause of large bowel obstruction. ${ }^{[4]}$ Peritoneal adhesions occurred in $93 \%$ of patients after abdominopelvic surgery; however, only $5 \%$ were symptomatic. Colorectal operations, gynecological surgery, and appendectomy are the most common primary surgery sources of peritoneal adhesions. The frequency of obstruction due to hernia has decreased with increased application of elective surgery. Tumors located distal to the splenic flexure are the most frequent cause of tumoral obstruction. Volvulus is another common reason for large bowel obstruction encountered in developing or eastern countries. ${ }^{[5]}$

Conservative management is commonly used for an adhesive obstruction; however, resection is typically used for tumoral obstructions. Sometimes surgical palliation can be performed for passage continuity. Enteroclysis or endoscopic stent implementation is an alternative nonsurgical treatment for uncomplicated obstructions. ${ }^{[2,3]}$

The AMBO mortality rate has been reported to be between $1.5 \%$ and $11.5 \%$ in the literature. Age, etiology, bowel necrosis, and comorbidities are risk factors for mortality and morbidity and considerations in management. ${ }^{[6,7]}$ The aim of this study was to evaluate the etiology, management, and survival of AMBO patients based on the records of 5 years at a training and research hospital in Turkey.

\section{MATERIALS AND METHODS}

After receiving institutional approval from the ethics committee of Okmeydanı Training and Research Hospital (08.01.2019/ 1088), the records of patients who hospitalized due to ileus and/or acute bowel obstruction between January 2014 and December 2018 were evaluated retrospectively. $\mathrm{Pa}-$ tients diagnosed with mechanical bowel obstruction, Ogilvie syndrome (acute colonic pseudo-obstruction [ACPO]), paralytic ileus (PI), or suspicion of a primary tumor ileus (SPTI), which may be clinically and/or radiologically compatible but excluded by colonoscopy, were included in the study.

Age, sex, etiology, management, and survival were evaluated for all-type AMBO, AMSBO, and AMLBO. The approach to management of $A M B O$ may be conservative, or surgical palliation or resection, with herniorrhaphy \pm mesh for hernia cases. Records of death during hospitalization were used to determine survival data.

Adhesions were categorized as primary benign or malignant, and details of primary surgery, management, and survival were analyzed. Primary adhesion surgery included upper gas- trointestinal system (GIS) surgery, colorectal surgery, hepaticopancreaticobiliary surgery, appendectomy, gynecological surgery, urological surgery, laparotomy, and hernia surgery.

Tumors were evaluated according to the location, patient sex, pathology, management, and survival. The location and characterization of the tumor was classified as small bowel, cecum, right colon, hepatic flexure, transverse colon, splenic flexure, left colon, sigmoid colon, rectosigmoid, rectum, recurrence, or non-gastrointestinal tumor. The pathology of tumors was assessed as none (no surgical pathology because of non-resection management), adenocarcinoma, mucinous carcinoma, invasion of other cancer, lymphoma/neuroendocrine tumor (NET), or benign.

Hernias were evaluated by type, primary surgery, management, and survival. Hernias were divided according to type and side. Primary surgery for incisional hernia consisted of GIS, gynecological, or hernia surgery.

Peritoneal carcinomatosis (PC) as a primary malignancy was categorized as upper GIS, colorectal, hepaticopancreaticobiliary, gynecological, urological, breast, or of unknown origin.

The statistical analysis was performed with SPSS for Windows, Version 16.0 (SPSS Inc., Chicago, IL, USA). A onesample T-test was used for age (mean $\pm S D$ ). The variables of males, females, etiology, management, and survival were evaluated as a percentage.

\section{RESULTS}

A total of 735 ( $9.2 \%$ of all hospitalizations) patients were included in the study. In all, 443 (60\%) patients had AMSBO, 292 (40\%) patients had AMLBO. The mean age was $59.9 \pm 16.02$ years for the overall AMBO group, $56.77 \pm 16.37$ years for AMSBO, and $64.36 \pm 14.48$ years for AMLBO. Total AMBO statistics revealed that $A C P O$ patients were the oldest group, with a mean age of $74.92 \pm 12$. 17 years, and diverticulitis was the most common etiology in the youngest group at $34.20 \pm 23.43$ years. In this study group, $52.9 \%$ of the patients were male, $47.1 \%$ were female. The percentage of female patients was greater in the hernia group (75\%), while male patients were the majority in the SPTI group (78.8\%). The overall mortality rate was $8.6 \%$. Tumor (39.7\%) was the most common reason for mortality, and adhesions and PC were the next most common reason for mortality $(22.2 \%$ and $12.7 \%$, respectively).

AMBO analysis indicated that adhesion was the most common etiological factor (43.3\%). Tumors and hernias were the other etiological factors seen most frequently $(26.2 \%$ and $6 \%$, respectively). The most common management approach for AMBO was conservative management (53.2\%). Surgical palliation was performed in $24.9 \%$ and surgical resection was performed in $21.9 \%$ of patients. Conservative management was pursued for most cases of adhesion (76.7\%), while sur- 
gical palliation was performed for PC (65.7\%), and surgical resection was performed for volvulus (6I.9\%) (Table I).

In AMSBO patients, adhesion was the most common etiological factor (69.3\%). Hernia and PC were the other etiological factors most often observed $(9.5 \%$ and $4.7 \%$, respectively).
The most common approach for AMSBO was conservative management (69\%). Surgical palliation was performed in $23 \%$ and surgical resection was performed in $8 \%$. Conservative management was most often used for adhesions (79.4\%), surgical palliation for bezoar (81.8\%), and surgical resection for diverticulitis (Meckel's) (100\%) (Table 2).

Table I. Distribution of etiology for AMBO

\begin{tabular}{|c|c|c|c|c|c|c|c|c|c|c|}
\hline \multirow[t]{2}{*}{ Etiology } & \multirow{2}{*}{$\begin{array}{c}\text { Age, years } \\
\text { (Mean } \pm \text { SD) }\end{array}$} & \multicolumn{2}{|c|}{ Sex } & \multicolumn{3}{|c|}{ Treatment } & \multicolumn{2}{|c|}{ Survival } & \multirow[t]{2}{*}{ Total } & \multirow[t]{2}{*}{$\%$} \\
\hline & & $\mathbf{M}$ & $\mathbf{F}$ & Conservative & Palliation & Resection & Yes & No & & \\
\hline Adhesion & $56.30 \pm 16.33$ & 154 & 164 & 244 & 54 & 20 & 304 & 14 & 318 & 43.3 \\
\hline Tumor & $62.94 \pm|3.6|$ & 115 & 77 & 23 & 64 & 105 & 167 & 25 & 192 & 26.2 \\
\hline Hernia & $62 .|4 \pm| 5.3 \mid$ & II & 33 & II & 21 & 12 & 41 & 3 & 44 & 6 \\
\hline Peritoneal carcinomatosis & $58.34 \pm 12.11$ & 15 & 23 & 11 & 25 & 2 & 30 & 8 & 38 & 5.2 \\
\hline \multicolumn{11}{|l|}{ Suspicion of primary } \\
\hline tumor ileus & $66.48 \pm 13.83$ & 26 & 7 & 33 & 0 & 0 & 32 & 1 & 33 & 4.5 \\
\hline Inflammatory bowel disease & $54.67 \pm 18.95$ & 14 & 10 & 19 & 3 & 2 & 23 & 1 & 24 & 3.2 \\
\hline Volvulus & $70.8 I \pm 17.25$ & 15 & 6 & 6 & 2 & 13 & 17 & 4 & 21 & 2.9 \\
\hline Paralytic ileus & $62.86 \pm 15.37$ & 8 & 6 & 14 & 0 & 0 & 13 & 1 & 14 & 1.9 \\
\hline \multicolumn{11}{|l|}{ Acute colonic } \\
\hline pseudo-obstruction & $74.92 \pm 12.17$ & 6 & 6 & 7 & 3 & 2 & 8 & 4 & 12 & 1.6 \\
\hline Bezoar & $57.91 \pm 16.80$ & 6 & 5 & 2 & 9 & 0 & II & 0 & II & 1.5 \\
\hline Gastric outlet obstruction & $55.25 \pm 21.37$ & 5 & 3 & 0 & 7 & 1 & 7 & $\mathrm{I}$ & 8 & I.I \\
\hline Diverticulitis & $34.20 \pm 23.43$ & 4 & I & 2 & 0 & 3 & 5 & 0 & 5 & 0.7 \\
\hline Other & $66 .|4 \pm| 5.3 \mid$ & 10 & 5 & 12 & 1 & 2 & 14 & I & 15 & 1.9 \\
\hline Total & $59.9 \pm 16.02$ & 389 & 346 & 384 & 189 & 162 & 672 & 63 & 735 & 100 \\
\hline
\end{tabular}

AMBO: Acute mechanical bowel obstruction; M: Male; F: Female; SD: Standard deviation.

Table 2. Distribution of etiology for AMSBO

\begin{tabular}{|c|c|c|c|c|c|c|c|c|c|c|}
\hline \multirow[t]{2}{*}{ Etiology } & \multirow{2}{*}{$\begin{array}{l}\text { Age, years } \\
\text { (Mean } \pm S D)\end{array}$} & \multicolumn{2}{|c|}{ Sex } & \multicolumn{3}{|c|}{ Treatment } & \multicolumn{2}{|c|}{ Survival } & \multirow[t]{2}{*}{ Total } & \multirow[t]{2}{*}{$\%$} \\
\hline & & $\mathbf{M}$ & $\mathbf{F}$ & Conservative & Palliation & Resection & Yes & No & & \\
\hline Adhesion & $56.18 \pm 16.54$ & 157 & 150 & 244 & 48 & 15 & 296 & 11 & 307 & 69.3 \\
\hline Hernia & $62.19 \pm 15.4 \mid$ & 10 & 32 & II & 21 & 10 & 39 & 3 & 42 & 9.5 \\
\hline Peritoneal carcinomatosis & $56.48 \pm 11.60$ & 4 & 17 & 9 & 12 & 0 & 17 & 4 & 21 & 4.7 \\
\hline Inflammatory bowel disease & $52.00 \pm 15.17$ & 8 & 7 & 12 & 2 & 1 & 14 & 1 & 15 & 3.4 \\
\hline Paralytic ileus & $62.86 \pm 15.37$ & 8 & 6 & 14 & 0 & 0 & 13 & 1 & 14 & 3.2 \\
\hline Tumor & $58.00 \pm 12.30$ & 7 & 5 & 1 & 7 & 4 & 8 & 4 & 12 & 2.7 \\
\hline Bezoar & $57.91 \pm 16.80$ & 6 & 5 & 2 & 9 & 0 & II & 0 & II & 2.5 \\
\hline Gastric outlet obstruction & $55.25 \pm 21.38$ & 5 & 3 & 0 & 7 & 1 & 7 & 1 & 8 & 1.8 \\
\hline Diverticulitis & $19.00 \pm 2.65$ & 3 & 0 & 0 & 0 & 3 & 3 & 0 & 3 & 0.7 \\
\hline Other & $61.50 \pm 16.24$ & 6 & 4 & 6 & 2 & 2 & 9 & 1 & 10 & 2.2 \\
\hline Total & $56.77 \pm 16.37$ & 214 & 229 & 299 & 108 & 36 & 417 & 26 & 443 & 100 \\
\hline
\end{tabular}

AMSBO: Acute mechanical bowel obstruction; M: Male; F: Female; SD: Standard deviation. 
For AMLBO patients, a tumor was the most common etiological factor (6I.6\%). SPTI and volvulus were the other etiological factors most often seen $(1 \mathrm{I} .3 \%$ and $7.2 \%$, respectively). The management approach for AMLBO most often applied was surgical resection (43.5\%). Surgical palliation was performed in $28.8 \%$ and conservative management in $27.8 \%$. Surgical resection was performed most for tumors (56.1\%), surgical palliation was performed for PC (76.5\%), and conservative management was applied for SPTI (100\%) (Table 3). The distribution of adhesion data is shown in Table 4. The mean age was $56.30 \pm 16.33$ years. In all, I 54 (48.4\%) patients were male and 164 (51.6\%) patients were female. Among this group, $54.4 \%$ underwent surgery for malignant disease. The most common primary malignancy was colorectal cancer (51.4\%). Conservative management was pursued for $76.7 \%$, surgical palliation was performed for $17 \%$, and surgical resection was performed for $6.3 \%$. Magnetic resonance enteroclysis was performed in $6.3 \%$ and surgical adhesiolysis in $10.4 \%$. The most common primary operation was colorectal surgery (29.5\%), followed by gynecological (23.2\%) and upper

Table 3. Distribution of etiology for AMLBO

\begin{tabular}{|c|c|c|c|c|c|c|c|c|c|c|}
\hline \multirow[t]{2}{*}{ Etiology } & \multirow{2}{*}{$\begin{array}{l}\text { Age, years } \\
\text { (Mean } \pm \text { SD) }\end{array}$} & \multicolumn{2}{|c|}{ Sex } & \multicolumn{3}{|c|}{ Treatment } & \multicolumn{2}{|c|}{ Survival } & \multirow[t]{2}{*}{ Total } & \multirow[t]{2}{*}{$\%$} \\
\hline & & $\mathbf{M}$ & $\mathbf{F}$ & Conservative & Palliation & Resection & Yes & No & & \\
\hline Tumor & $63.27 \pm 13.67$ & 108 & 72 & 22 & 57 & 101 & 159 & 21 & 180 & 61.6 \\
\hline \multicolumn{11}{|l|}{ Suspicion of primary } \\
\hline tumor ileus & $66.48 \pm 13.83$ & 26 & 7 & 33 & 0 & 0 & 32 & $\mathrm{I}$ & 33 & 11.3 \\
\hline Volvulus & $70.81 \pm 17.26$ & 15 & 6 & 6 & 2 & 13 & 17 & 4 & 21 & 7.2 \\
\hline Peritoneal carsinomatosis & $60.65 \pm 12.70$ & 11 & 6 & 2 & 13 & 2 & 13 & 4 & 17 & 5.8 \\
\hline \multicolumn{11}{|l|}{ Acute colonic } \\
\hline pseudo-obstruction & $74.92 \pm 12.18$ & 6 & 6 & 7 & 3 & 2 & 8 & 4 & 12 & 4.1 \\
\hline Adhesion & $59.64 \pm 12.82$ & 4 & 7 & 0 & 5 & 6 & 8 & 3 & II & 3.8 \\
\hline Inflammatory bowel disease & $59.11 \pm 24.38$ & 6 & 3 & 7 & 1 & 1 & 9 & 0 & 9 & 3.1 \\
\hline Diverticulitis & $57.00 \pm 21.21$ & 1 & I & 2 & 0 & 0 & 2 & 0 & 2 & 0.7 \\
\hline Ischemic colitis & $74.00 \pm 2.83$ & I & 1 & 2 & 0 & 0 & 2 & 0 & 2 & 0.7 \\
\hline Hernia & $61.00 \pm 18.38$ & 1 & 1 & 0 & 0 & 2 & 2 & 0 & 2 & 0.7 \\
\hline Other & $74.00 \pm 9.85$ & 3 & 0 & 3 & 0 & 0 & 3 & 0 & 3 & 1 \\
\hline Total & $64.36 \pm 14.48$ & 182 & 110 & 84 & 81 & 127 & 255 & 37 & 292 & 100 \\
\hline
\end{tabular}

AMLBO: Acute mechanical bowel obstruction; M: Male; F: Female; SD: Standard deviation.

Table 4. Evaluation of $A M B O$ due to adhesions

\begin{tabular}{|c|c|c|c|c|c|c|c|c|c|c|c|}
\hline \multirow[t]{2}{*}{ Primary surgery } & \multicolumn{2}{|c|}{ Sex } & \multicolumn{2}{|c|}{ Malignant/Benign } & \multicolumn{4}{|c|}{ Treatment } & \multicolumn{2}{|c|}{ Survival } & \multirow[t]{2}{*}{ Total (\%) } \\
\hline & M & $\mathbf{F}$ & Malignant & Benign & Conservative & Adhesiolysis & Palliation & Resection & Yes & No & \\
\hline Colorectal surgery & 48 & 46 & 89 & 5 & 81 & 0 & II & 2 & 70 & 7 & $94(29.5)$ \\
\hline Gynecological surgery & 0 & 74 & 46 & 28 & 51 & 9 & 6 & 8 & 73 & 1 & $74(23.2)$ \\
\hline Upper GIS surgery & 50 & 10 & 26 & 34 & 50 & 3 & 2 & 5 & 57 & 3 & $60(18.9)$ \\
\hline Appendectomy & 17 & 8 & 0 & 25 & 16 & 7 & 0 & 2 & 25 & 0 & $25(7.9)$ \\
\hline Laparotomy & 15 & 9 & 0 & 24 & 13 & 9 & 1 & 1 & 24 & 0 & $24(7.5)$ \\
\hline Urological surgery & 10 & 5 & 10 & 5 & 11 & 2 & 1 & I & 13 & 2 & $15(4.7)$ \\
\hline Hernia surgery & 7 & 7 & 0 & 14 & 10 & 3 & 0 & 1 & 13 & $\mathrm{I}$ & $14(4.4)$ \\
\hline \multicolumn{12}{|l|}{ Hepatopancreato } \\
\hline biliary surgery & 7 & 5 & 2 & 10 & 12 & 0 & 0 & 0 & 12 & 0 & 12 (3.9) \\
\hline Total & 155 & 163 & 173 & 145 & 244 & 33 & 21 & 20 & 304 & 14 & 318 \\
\hline
\end{tabular}

AMBO: Acute mechanical bowel obstruction; GIS: Gastrointestinal system; M: Male; F: Female. 


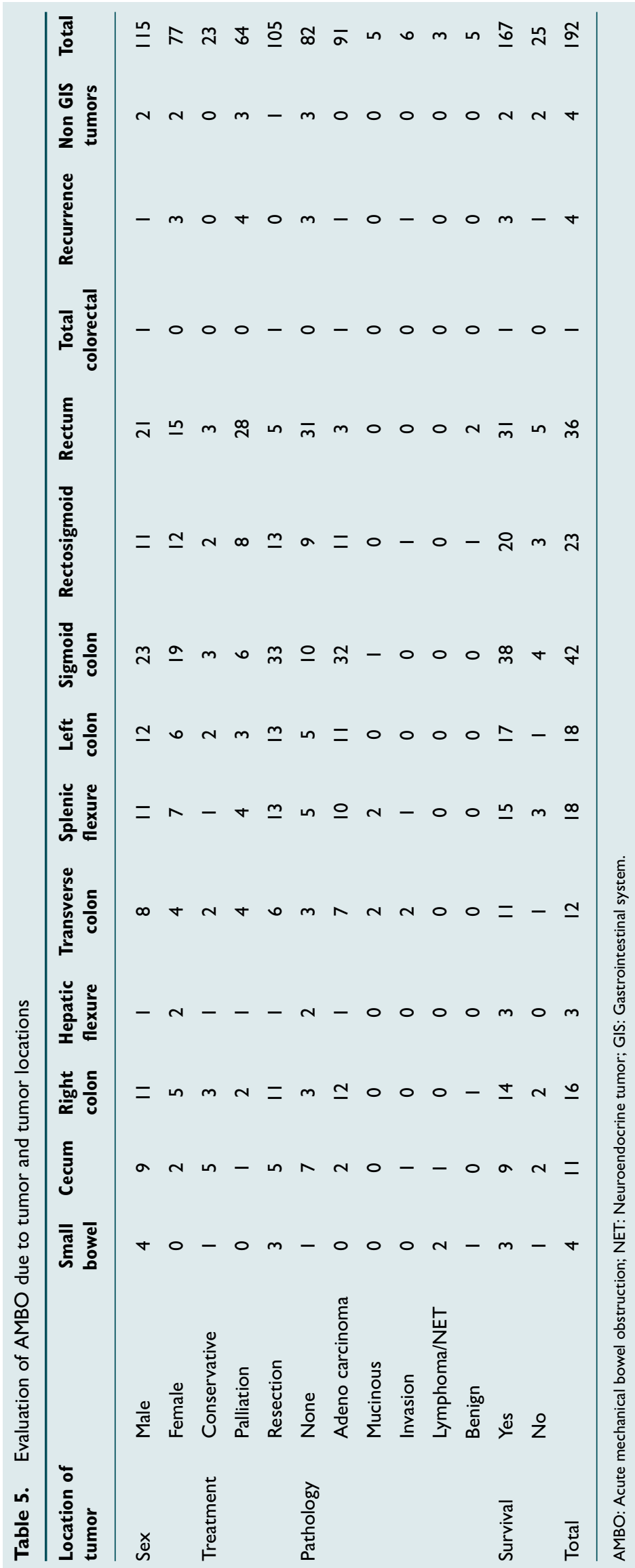

GIS (I8.9\%) surgery. The mortality rate was $4.4 \%$ $(n=14) ; 50 \%$ of these occurred following colorectal surgery.

The distribution of tumor locations is illustrated in Table 5. The mean age of those with a tumor was $62.94 \pm 13.61$ years. In this group, II 5 (59.9\%) patients were male and $77(40.1 \%)$ patients were female. Surgical resection was performed in $54.7 \%$, surgical palliation in $33.3 \%$, and $12 \%$ were managed conservatively. The pathology was reported as $42.7 \%$ none, $47.4 \%$ adenocarcinoma, $2.6 \%$ mucinous carcinoma, $3.1 \%$ invasion, $2.6 \%$ lymphoma/ NET, and $1 / 6 \%$ benign pathology. The mortality rate was $13 \%(n=25)$. The most common location of the tumor was the sigmoid colon $(n=42,21.9 \%)$, followed by the rectum $(n=36,18.7 \%)$ and the rectosigmoid $(n=23,12 \%)$. Tumors located distal to the sigmoid colon comprised $52.6 \%$ and tumors distal to the splenic flexure represented $71.3 \%$. One patient underwent a total proctocolectomy with ileoanal anastomosis due to attenuated familial adenomatous polyposis.

The hernia distribution is shown in Table 6. The mean patient age was $62.14 \pm 15.31$ years. There were II (25\%) male patients and 33 (75\%) were female. In all, $25 \%$ of the patients were managed conservatively; herniorrhaphy \pm mesh was performed in $47.7 \%$ and surgical resection was performed in $27.3 \%$. The most common type of hernia observed in the group was an incisional hernia (47.7\%), followed by an inguinal hernia (18.2\%), and an umbilical hernia (II.4\%). In 75\% $(n=6)$ of those with an inguinal hernia and in $66 \%(n=2)$ of those with a femoral hernia, the hernia was located on the right side. The most common reason for an incisional hernia was GIS surgery ( $57.1 \%$ ), followed by hernia surgery $(23.8 \%)$ and gynecological surgery $(19.1 \%)$. The mortality rate in this group was $6.8 \%(n=3)$ and all were patients with an incisional hernia.

PC was the fourth most common cause of AMBO: $43.6 \%(n=17)$ occurred as a result of colorectal cancers, $30.8 \%(n=12)$ from gynecological cancers, and the remainder were of upper GIS, hepaticopancreaticobiliary, breast, urological, or unknown cancer origin. In all, $26.3 \%$ of the patients were managed conservatively, surgical palliation was performed in $65.8 \%$, and surgical resection in $7.9 \%$. The mortality rate was $21 \%(n=8)$ (Table 7$)$.

The incidence of inflammatory bowel disease was determined to be $3.2 \%$ in the total AMBO group: $3.4 \%$ in those with AMSBO and $3.1 \%$ in the AMLBO patients. Conservative management was 
Table 6. Evaluation of AMBO due to hernia

\begin{tabular}{|c|c|c|c|c|c|c|c|c|c|c|c|c|c|}
\hline \multirow[t]{2}{*}{ Type } & & \multicolumn{2}{|c|}{ Sex } & \multicolumn{3}{|c|}{ Treatment } & \multicolumn{4}{|c|}{ Primary surgery } & \multicolumn{2}{|c|}{ Survival } & \multirow[t]{2}{*}{ Total } \\
\hline & & $\mathbf{M}$ & $\mathbf{F}$ & Conservative & $\begin{array}{c}\text { Herniorrhaphy } \pm \\
\text { Mesh }\end{array}$ & Resection & None & GIS & Gynecological & Hernia & Yes & No & \\
\hline Incisional & & 3 & 18 & 5 & 8 & 8 & 0 & 12 & 4 & 5 & 18 & 3 & 21 \\
\hline \multirow[t]{2}{*}{ Inguinal } & $\mathrm{R}: 6$ & 6 & 2 & 2 & 5 & I & 8 & 0 & 0 & 0 & 8 & 0 & 8 \\
\hline & $\mathrm{L}: 2$ & & & & & & & & & & & & \\
\hline Umbilical & & 0 & 5 & 2 & 3 & 0 & 5 & 0 & 0 & 0 & 5 & 0 & 5 \\
\hline Diaphragmatic & & 1 & 4 & 2 & 2 & 1 & 3 & I & 0 & 1 & 5 & 0 & 5 \\
\hline \multirow[t]{2}{*}{ Femoral } & $\mathrm{R}: 2$ & 0 & 3 & 0 & 3 & 0 & 3 & 0 & 0 & 0 & 3 & 0 & 3 \\
\hline & L:I & & & & & & & & & & & & \\
\hline Internal & & 1 & 1 & 0 & 0 & 2 & 0 & I & 1 & 0 & 2 & 0 & 2 \\
\hline Total & & II & 33 & II & 21 & 12 & 19 & 14 & 5 & 6 & 41 & 3 & 44 \\
\hline
\end{tabular}

AMBO: Acute mechanical bowel obstruction; GIS: Gastrointestinal system; M: Male; F: Female.

Table 7. Evaluation of AMBO due to peritoneal carcinomatosis

\begin{tabular}{|c|c|c|c|c|c|c|c|c|}
\hline \multirow[t]{2}{*}{ Primary malignancy } & \multicolumn{2}{|c|}{ Sex } & \multicolumn{3}{|c|}{ Treatment } & \multicolumn{2}{|c|}{ Survival } & \multirow[t]{2}{*}{ Total } \\
\hline & Male & Female & Conservative & Palliation & Resection & Alive & Exitus & \\
\hline Upper GIS & 1 & 2 & 3 & 0 & 0 & 3 & 0 & 3 \\
\hline Colorectal & $\mathrm{II}$ & 6 & I & 13 & 3 & 13 & 4 & 17 \\
\hline Hepatopancreato biliary & 1 & 1 & 0 & 2 & 0 & 2 & 0 & 2 \\
\hline Gynecological & 0 & 12 & 4 & 8 & 0 & 10 & 2 & 12 \\
\hline Urological & 1 & 0 & 0 & I & 0 & 0 & I & 1 \\
\hline Breast & 0 & 2 & I & 1 & 0 & I & I & 2 \\
\hline Unknown origin & 1 & 0 & 1 & 0 & 0 & 1 & 0 & 1 \\
\hline Total & 15 & 23 & 10 & 25 & 3 & 30 & 8 & 38 \\
\hline
\end{tabular}

AMBO: Acute mechanical bowel obstruction; GIS: Gastrointestinal system.

applied in $79.2 \%$ of patients and surgery was performed in $20.8 \%$ ( $12.5 \%$ palliation, $8.3 \%$ resection). Mortality was $4.2 \%$ $(n=l$; small bowel obstruction) in this group.

The AMBO incidence of colonic volvulus was $2.9 \%$ and $7.2 \%$ were AMLBO cases. The mean patient age was $70.8 \mathrm{I} \pm 17.25$ years and the male/female proportion was 2.5:I (15/6). In this group, $61.9 \%(n=13)$ underwent a Hartmann procedure or resection and anastomosis, 9.5\% $(n=2)$ a surgical detorsion and $28.6 \%$ a colonoscopic decompression. The mortality rate was $19 \%(n=4)$.

The total incidence of bezoars was $1.5 \%$. Of those, $18.2 \%$ were managed conservatively and $81.8 \%$ were treated surgically ( $27.2 \%$ milking, $54.6 \%$ enterotomy). No mortality occurred among the bezoar patients in the study.

The incidence of gastric outlet obstruction (GOO) was I.I\%. Palliation was the most common management approach, ap- plied to $87.5 \%$, while gastrojejunostomy was performed for $12.5 \%(n=1)$. The mortality rate was $12.5 \%(n=1)$.

Diverticulitis was determined in the AMBO group in $0.7 \%$ $(n=5): 40 \%$ were AMLBO patients and $60 \%$ were AMSBO (Meckel's diverticulitis). All of the large bowel diverticulitis cases were managed conservatively; however, a diverticulectomy was performed for those with small bowel diverticulitis (Meckel's). No mortality was seen in the diverticulitis patients.

In this study group, $33(4.5 \%)$ patients were hospitalized for SPTI evaluation. The mean age was $66.48 \pm 13.83$ years. All of the patients were managed conservatively and underwent a colonoscopy for further evaluation. A total of $3 \%(n=I)$ died due to comorbidities.

The incidence of $\mathrm{PI}$ was $1.9 \%$ in the AMBO group. Concomitant malignancy was found in I patient, neurological disorders in 2 patients, and chronic renal failure in 6 patients. All of 
the patients were managed conservatively. The mortality rate was $7.1 \%(n=1)$.

The ACPO incidence was found to be $1.6 \%$ overall. Concomitant neurological disorders were found in 6 patients, cardiac disorders in 9 patients, and a psychiatric disorder in I patient. In this group, $58.3 \%$ were treated conservatively with neostigmine and an enema. An ostomy was performed in $25 \%$ $(n=3)$ and resection in $16.7 \%(n=2)$. The rate of mortality was $25 \%(n=3)$; I patient died due to aspiration and 2 patients died after surgery.

The incidence of rare etiological factors was 1.9\%. These were development post endoscopic retrograde cholangiopancreatography, globe vesicale, ischemic colitis, cecal intramural hematoma, splenic infarct, ileocolic fistula, rectal ulcer, mesenteric ischemia, gallstone ileus, cocoon, and tuberculosis peritonitis. A total of $80 \%$ of the patients were managed conservatively, surgical palliation was performed for $6.7 \%$, and surgical resection was performed for $13.3 \%$. The mortality rate was $6.7 \%(n=1)$ (gallstone ileus).

\section{DISCUSSION}

$\mathrm{AMBO}$ was an important surgical problem in the past, is still a problem today, and will continue to be one in the future. Hernia and volvulus remain important causes of obstruction; however, adhesions are the most common reason for AMBO. The incidence of $A M B O$ as a result of a tumor or $P C$ has also increased with the prolongation of human life and the advances of development.

Pędziwiatr et al. ${ }^{[8]}$ reported a mean age of 38.5 years in AMBO patients before the $20^{\text {th }}$ century, while more recently, it has increased to 63.9 years. Markogiannakis et al. ${ }^{[3]}$ found a mean age of $63.8 \pm 1.3$ years. Akcakaya et al. ${ }^{[5]}$ reported a mean age of tumoral patients of $58 \pm 13$ years and $49 \pm 20$ years among non-tumoral patients. In the present study, the mean of age was $59.9 \pm 16.02$ years in the total AMBO group, while it was $56.77 \pm 16.37$ years in patients with AMSBO and 64.36 \pm 14.48 years in those with AMLBO. The most common cause of AMLBO was a tumor (61.6\%). Consistent with the literature, the mean age of those with large bowel obstruction was greater than those with small bowel obstruction.

The proportion of males has been greater than that of females in some studies $(51.8 \%$ to $74 \%),{ }^{[5,9,10]}$ but in other research the female proportion was greater (60\%). ${ }^{[3,8]}$ Pędziwiatr et al. ${ }^{[8]}$ noted that the female proportion increased from $47.8 \%$ to $60.2 \%$ over time. Akcakaya et al. reported that the male proportion was greater in both the tumoral and non-tumoral groups. ${ }^{[3]}$ We determined a male/female ratio of $389 / 346$ (52.9\%/47.1\%) in AMBO cases: $214 / 229$ (48.3\%/51.7\%) in the AMSBO group and $182 / 110(62.3 \% / 37.7 \%)$ in the AMLBO group. There was a larger proportion of female patients in the AMSBO (non-tumoral) group.
$\mathrm{AMBO}$ has been observed in the small bowel in approximately $75 \%$ to $80 \%$ of cases in the literature, and $20 \%$ to $25 \%$ in the large bowel. ${ }^{[3]}$ In our study, the incidence of AMBO was $60 \%$ in the small bowel and $40 \%$ in the large bowel. The difference in this ratio may be due to the fact that those patients with acute small bowel obstruction, especially due to adhesions, for whom intestinal passage could be provided without requiring hospitalization, were not included in the study.

The most common causes of AMBO are adhesions, tumors, and hernias in Europe and the USA (60-68.4\%, 15.4-20\%, $10-14.8 \%$, respectively). ${ }^{[3,11]}$ In the last 50 years, the incidence of strangulated hernia has decreased from $55.8 \%$ to $26.5 \%$, while tumors increased from $6.3 \%$ to $22.2 \%$ and adhesions remained statistically unchanged. ${ }^{[8]}$ Volvulus and intussusception were reported to be the most common causes of AMBO in Ethiopia, ${ }^{[12]}$ and hernia remained the most common cause of intestinal obstruction in Sudan in some research. ${ }^{[13]}$ The etiology of AMBO has varied over time and according to geographic region in Turkey. External hernias have been cited as the most common cause of AMBO (37.9-45\%), followed by volvulus, tumors, and adhesions $(28.6 \%, 27 \%, 35.1 \%$, respectively). ${ }^{[14-18]}$

The most common etiology of AMBO as well as AMSBO in the literature is peritoneal adhesions. Adhesions reportedly occurred in $63 \%$ to $97 \%$ of all abdominopelvic surgery patients, but only $5 \%$ were symptomatic. Pelvic pain, infertility, and mechanical bowel obstruction are frequent complications of adhesions. ${ }^{[19,20]}$ Parker et al. ${ }^{[21]}$ described a risk of readmission after duodenum and jejunum surgery of $1.8 \%$, ileum surgery $7.7 \%$ ( $10.6 \%$ ileostomy, $7 \%$ ileal resection), colon surgery $5 \%$, rectal surgery $5.2 \%$ (15.4\% total proctocolectomy, $8.8 \%$ total colectomy), and appendectomy $0.9 \%$ (The Surgical and Clinical Adhesions Research [SCAR-3] study). The rate of abdominal reoperation required due to adhesion was $30 \%$ to $41 \%$, and increased to $65 \%$ to $75 \%$ in the small bowel. Surgery in the transverse mesocolon has also caused obstructive adhesions. ${ }^{[22]}$ Ten Broek et al. ${ }^{[23]}$ reviewed the incidence of adhesive small bowel obstruction according to the type of operation. They found that pediatric surgery had the highest incidence rate at $4.2 \%$, followed by gastrointestinal surgery at $3.2 \%$, hepatopancreaticobiliary surgery at $2.2 \%$, gynecological surgery at $2.1 \%$, urological surgery at $1.5 \%$, upper gastrointestinal surgery at $1.2 \%$, and abdominal wall surgery at $0.5 \%$. The incidence after laparotomy was reported as $3.8 \%$ and $2.7 \%$ after laparoscopy. Barmparas et al. ${ }^{[24]}$ reviewed post-laparotomy adhesive small bowel obstruction. They reported that the most common cause of AMSBO was open adnexal surgery at $23.9 \%$, ileal pouch anastomosis at $19.3 \%$, followed by open total abdominal hysterectomy at $15.6 \%$, and open colectomy at $9.5 \%$. The incidence rate for an open appendectomy was $1.4 \%$ vs $1.3 \%$ for a laparoscopic appendectomy, but the rate for a laparoscopic cholecystectomy vs. an open cholecystectomy decreased from $0.2 \%$ to $7.1 \%$. In our study, the incidence of adhesions was $69.3 \%$ for AMSBO and 
43.3\% for AMBO. The most common cause of adhesions was colorectal surgery $(29.5 \%)$, followed by gynecological surgery (23.2\%) and upper GIS surgery (I8.9\%).

Adhesive AMBO can be managed conservatively or surgically. The literature records conservative treatment of adhesive AMBO in $20 \%$ to $73 \%$ of cases. ${ }^{[25]}$ Fluid resuscitation, electrolyte balancing, and nasogastric decompression are the initial treatments recommended for adhesive AMBO; however, while this initial treatment succeeds in some $80 \%$ of cases of partial obstruction, the rate is $40 \%$ for complete obstruction. ${ }^{[26]}$ Water-soluble oral contrast agents have been used for conservative management of adhesive AMBO. Oral contrast agents reduced the need for surgery ( $20 \%$ vs $29 \%$ in controls) and the therapeutic effects were evident after 24 hours. ${ }^{[27]}$ Operative management of adhesive AMBO initially requires exploration with either an open or laparoscopic approach. According to the etiology and/or patient comorbidities, adhesiolysis, or resection with or without anastomosis and palliation (bypass or ostomy) can be performed. A laparoscopic operation has some advantages, such as less pain, less bleeding, fewer surgical site infections, fewer adhesions, and a shorter hospital stay. However laparoscopic adhesiolysis requires experience, and has an increased bowel injury risk of $6.3 \%$ to $26.9 \%$ and may delay a diagnosis of perforation. ${ }^{[2]}$ The mortality rate of adhesive AMBO has decreased from $5.29 \%$ to $3.77 \%$ with timely operative management, but there is still a higher mortality risk than with conservative management. ${ }^{[29,30]}$ In the present study, $76.7 \%$ of adhesive AMBO cases were managed conservatively and only $23.3 \%$ underwent surgery. In all, $44.6 \%(n=33)$ of the surgical group had adhesiolysis and $15 \%(n=5)$ of the adhesiolysis procedures were performed laparoscopically. Surgical palliation (ileostomy, colostomy, or bypass) was performed (28.4\%) somewhat more than resection (27\%). The mortality rate of all adhesive AMBO patients in this study was $4.4 \%$ $(n=|4 / 3| 8)$, while it was $71.4 \%(n=10)$ among those who underwent surgical resection or palliation.

Tumors are the second most common cause of AMBO. Primary or metastatic tumors may obstruct the gastrointestinal passage. Colorectal and ovarian cancers are the most frequent types of tumoral AMBO. The incidence of tumoral AMBO overall is $3 \%$. The reported incidence of colorectal cancer varies from $10 \%$ to $28 \%$ and ovarian cancer varies from $5.5 \%$ to $51 \%$. The most frequently seen extra-peritoneal malignancies are breast cancer, lung cancer, and melanoma. ${ }^{[31,32]}$ Small bowel tumors are a very rare condition $(\mathrm{I}-\mathrm{I} .6 \%$ of gastrointestinal tract tumors) and $53 \%$ of these tumors present with AMSBO ${ }^{[33]}$ The sigmoid colon is the most common site of AMLBO. Research has indicated that $59.4 \%$ of tumors are seen distal to the splenic flexure and $34.6 \%$ of tumors are observed in the left colon and the sigmoid. ${ }^{[3,35]}$ The main treatment of tumoral AMBO is surgery for palliation or resection. Conservative management can be performed for patients with a partial obstruction in preparation for surgery or with neoad- juvant oncological treatment. Stents can be used for palliation or in preparation for surgery, but some complications have been recorded, such as stent migration (11\%), perforation (4.5\%), and re-obstruction (12\%). ${ }^{[36]}$ The pathology of tumors has been reported in the literature as $81.9 \%$ non-mucinous and $18.1 \%$ mucinous in cases of advanced-stage, obstructive, colorectal tumors. ${ }^{[3]}$ One study reported a mortality rate of $14 \%$ after surgery in tumoral AMBO. ${ }^{[34]}$ Our data revealed that among all the AMBO cases, $26.2 \%$ were tumoral. In all, $94 \%$ of the tumors arose from the large bowel, $2 \%$ the small bowel, $2 \%$ were recurrent, and $2 \%$ were non-gastrointestinal. Of the tumors in this study, $62 \%$ were distal to the splenic flexure and $31.2 \%$ were located in the left colon or the sigmoid. The incidence of tumoral AMBO and colorectal tumor in this study was greater than that seen in the literature, while the incidence of ovarian tumor was less. Conservative management was applied for $12 \%$, patients with a partial obstruction before elective surgery or prior to pathological diagnosis. Another $54.7 \%$ underwent a resection procedure, such as anterior resection, left or right hemicolectomy, etc., and 33.3\% received palliative care, such as an ileostomy or colostomy, for advanced tumors or frozen abdomen. Our experience with colonic stent placement was limited and was applied in only a few cases of tumoral AMBO. The pathology reports were $2 \%$ mucinous and $47.4 \%$ adenocarcinoma; $47.2 \%$ had no pathology due to palliation of tumoral obstructions. A smaller percentage of mucinous pathology than seen in the literature may be related to patients without pathology. The mortality rate was $13 \%$, which is consistent with the literature.

Hernia is still an important cause of AMBO in developing countries. The incidence has decreased from $30 \%$ to $15 \%$ in developed nations, in part, as a result of elective hernia surgery. Inguinal hernia is the most common type, with a proportion of $75 \%$, and there is a $29 \%$ incidence of strangulation. The incidence of strangulation of umbilical hernia has been reported at $60 \%$, incisional hernia at $50 \%$, and femoral hernia at $46 \%$. Internal, parastomal, and diaphragmatic hernias are other types of hernias that can lead to AMBO. Incisional hernia can occur after abdominal surgery in $2 \%$ to $50 \%$ of cases. Herniorrhaphy with or without mesh and bowel resection, and with or without anastomosis is the first treatment choice for hernia due to bowel strangulation, ischemia, or necrosis. ${ }^{[1,38]}$ In our study, the incidence of hernia leading to AMBO was $6 \%$, which is less than that seen in the literature. The most common type of strangulated hernia was an incisional hernia (47.7\%), which is also contrary to literature reports. Diaphragmatic hernia (11.4\%) was an important cause of AMBO in this study. Herniorrhaphy, with or without mesh, was the most common treatment $(47.7 \%)$ and bowel resection was performed in $66.6 \%$ of cases of incisional hernia. The mortality rate was $6.8 \%$ and all of these were cases of operated incisional hernia.

PC has been described as the peritoneal locoregional spread of tumoral cells. Epithelial ovarian cancer, colorectal cancer, 
gastric cancer, and pancreatic cancer are the most common causes of PC. The incidence of $A M B O$ as a result of $P C$ has been reported as $8 \%$ to $14 \%$. Some $75 \%$ of epithelial ovarian cancer cases are diagnosed at an advanced stage (PC). The reported PC incidence of colorectal cancer is $4 \%$ to $19 \%$, while for gastric cancer it is $53 \%$ to $60 \%$, and for pancreatic cancer it is $68.5 \%$; however, obstruction occurred most often in cases of colorectal cancer (19.7\% vs $0.07 \%, 10.3 \%$ respectively). AMBO due to PC may be treated with conservative management or surgery. Resection or palliation (ostomy or bypass) are the surgical choices. The overall mortality has been reported as $21 \% .^{[39-41]}$ In our study, the incidence of AMBO due to PC was $5.2 \%$, which is less than that reported in the literature. Colorectal cancer was the most common etiology of AMBO due to PC with $44.7 \%$, followed by gynecological (ovarian) cancer with $31.6 \%$, and gastric cancer with $2.5 \%$. Palliation surgery was the most common treatment at $65.8 \%$ and resection was performed in only $7.9 \%$. The overall mortality rate was $26 . \%$, which is greater than that reported in the literature. A total of $62.5 \%$ of mortality was seen after palliation surgery.

Inflammatory bowel disease (IBD) is another etiological factor of $\mathrm{AMBO}$, and particularly Crohn's disease. The occurrence of obstruction and the need for surgery is greater in the small bowel (35-54\%) than the large bowel (5-17\%). The inflammatory process, abscess, stricture, and the development of cancer are potential causes of obstruction of the bowel. The incidence of IBD has been reported as $0.7 \%$ for $A M B O$ and $7 \%$ for AMSBO. The inflammatory process or an abscess are initially treated conservatively (medical or percutaneous drainage). Stricture or tumors are managed surgically. A surgical intervention is performed to achieve palliation or resection of a strictured bowel. The standardized mortality rate for Crohn's disease has been reported as $1.2 \%$ and $0.8 \%$ for ulcerative colitis. The mortality rate has been decreased by performing surgery for severe complications or cancer development. ${ }^{[42,43]}$ In the present study, the incidence of IBD was $3.2 \%$ for the overall AMBO group, 3.4\% for AMSBO, and 3.1\% for AMLBO. This is a greater rate for the AMBO group than seen in the literature, while less for AMSBO. In all, $79.2 \%$ of patients were managed conservatively and surgery was performed only in cases of Crohn's disease (20.8\%) (12.5\% palliation, $8.3 \%$ resection). The mortality rate was as $4.2 \%(n=I$; small bowel obstruction).

Colonic volvulus (sigmoid colon) is another potential etiology of AMLBO. Colonic volvulus is endemic in Africa, South America, Russia, Eastern Europe, the Middle East, India, and Brazil. The incidence has been reported as 13\% to $42 \%$. North America, Western Europe, and Australia have a low incidence rate (5\%). The incidence has been reported as $80.2 \%$ in the eastern region of Turkey and $38.8 \%$ in the western portion of the country. The proportion of males was greater than that of females (4:I). Endemic volvulus is seen in the fourth decade of life, whereas it is more typically observed in the seventh decade in western countries. The management of colonic volvulus varies according to status: uncomplicated cases may be managed conservatively (colonoscopic decompression), while complicated cases (perforation, necrosis) generally require surgical intervention (Hartman procedure or resection anastomosis). The mortality rate of colonic volvulus has been reported as $9.44 \% .{ }^{[44-46]}$ The incidence of colonic volvulus in our study was $2.9 \%$ for the AMBO group and $7.2 \%$ among the AMLBO patients, which is less than rates reported in the national and international literature. The mean age was $70.81 \pm 17.25$ years and the male/female proportion was 2.5:I (15/6), which is similar to that reported in western countries. A Hartmann procedure or resection and anastomosis was performed for $61.9 \%(n=\mid 3)$, surgical detorsion was performed for $9.5 \%(n=2)$, and colonoscopic decompression for $28.6 \%$. The mortality rate was $19 \%(n=4)$, which is greater than that cited in the literature.

The incidence of bezoar leading to AMBO has been reported as $4 \%$. Some $65 \%$ had an anamnesis of previous surgery, especially gastric surgery. Bezoars are initially managed conservatively with bowel rest and hydration, including the intake of acidic fluids such as pineapple juice. Surgical intervention can include milking the colon, enterostomy, or bowel resection and anastomosis. The mortality rate has been reported as $4 \% .{ }^{[47,48]}$ Our data revealed an AMBO incidence of bezoars of $1.5 \%$. In all, 18.2 of the patients had a history of gastric surgery. Conservative management was applied for $18.2 \%$ of the bezoar patients, and $81.8 \%$ underwent surgery $(27.2 \%$ milking, 54.6\% enterotomy). A bezoar that was the result of an impacted stool could be milked to the colon, but seed formations required an enterotomy. No mortality was seen in our bezoar patients. The incidence, history of gastric surgery, and mortality rate was less than that reported in the literature.

$\mathrm{GOO}$ is the consequence of a blockage preventing gastric emptying, often due to gastric, duodenal, or pancreatic disease. Palliative management, such as endoscopic stent replacement, can be as effective as surgery (bypass). The mortality rate of palliative management has been reported as $3.9 \%$, while it is $2 \%$ to $36 \%$ in cases of surgical intervention.

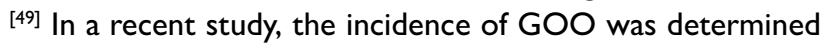
to be $1.1 \%$. Palliation was the most common management approach, applied to $87.5 \%$, and a gastrojejunostomy (primary breast cancer) was performed for $12.5 \%$. The mortality rate was $12.5 \%$ ( $n=I$; inoperable pancreas cancer).

Diverticulitis has been reported to develop in $10 \%$ to $25 \%$ of cases as a result of diverticular disease and $15 \%$ to $20 \%$ of diverticulitis cases may include the complication of obstruction. Among patients with colonic diverticulitis, the incidence of obstruction has been reported as $2.3 \%$. Two-thirds of cases of diverticulitis obstruction of the large bowel are managed surgically and $50 \%$ are managed with resection, with or without anastomosis. The mortality rate has been reported as $2.6 \%$. ${ }^{[5]}$ Meckel's diverticulum is the most frequently seen 


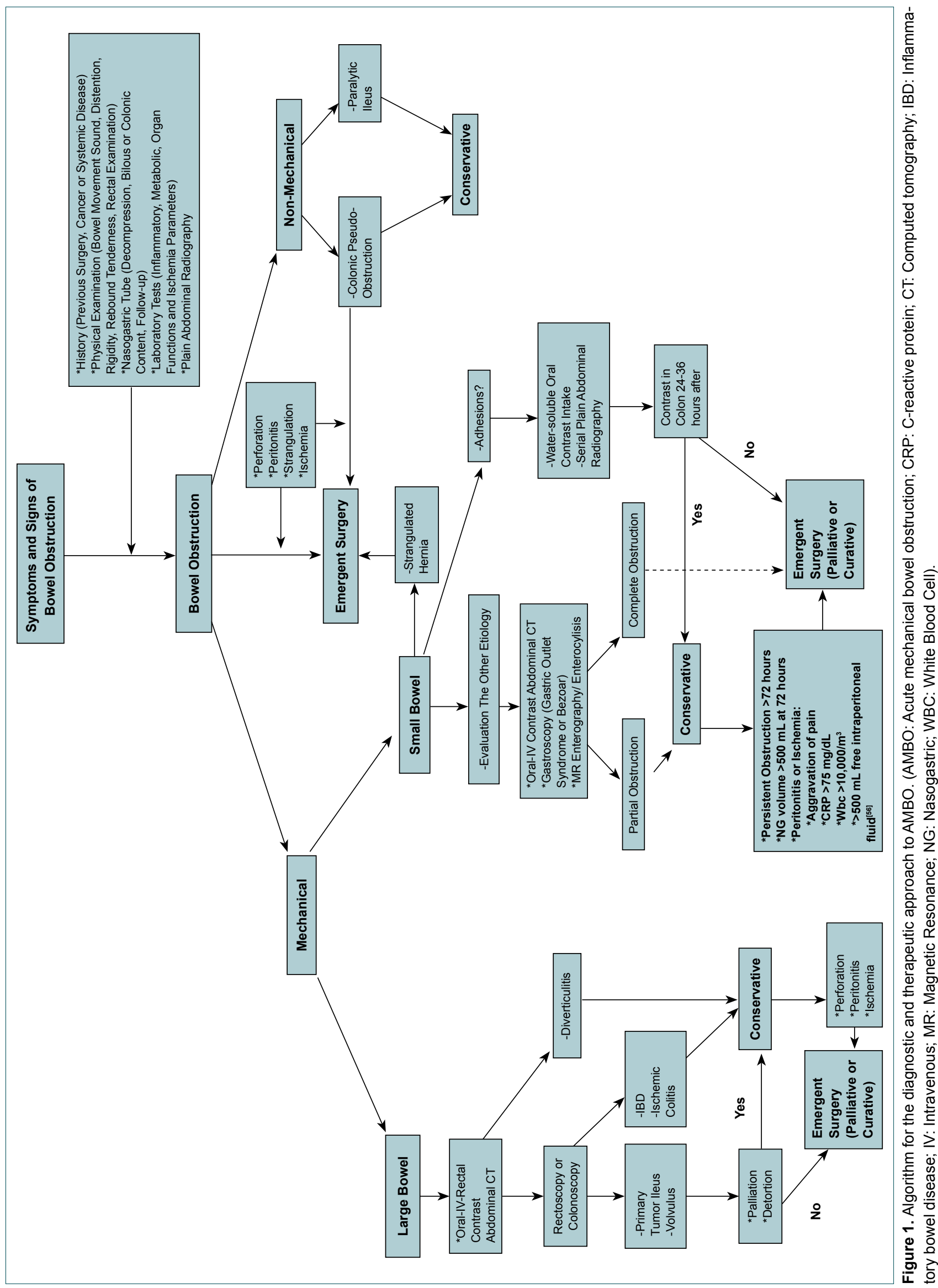


gastrointestinal tract congenital anomaly in these patients, with a $2 \%$ incidence. Meckel's diverticulum has $4 \%$ to $6 \%$ risk of complication over a lifetime, and intestinal obstruction is the most common in adults. The management of Meckel's diverticulitis with complications is usually a diverticulectomy or bowel resection. ${ }^{[51]}$ In our study, the incidence of diverticulitis in the AMBO group was $0.7 \%(n=5)$. Of those, $40 \%$ occurred in the large bowel, and $60 \%$ in the small bowel (Meckel's diverticulitis). A diverticulectomy was performed for all of the small bowel diverticulitis (Meckel's) patients. No mortality was seen in the diverticulitis patient group.

Colorectal cancer is the second most common cancer in the world. Age $>50$ years, a family history of the disease, anemia, and changes in defecation habits are some risk factors associated with colorectal cancers. AMBO can be a reason for hospital admission for patients with colorectal cancers. Contrast-enhanced computed tomography (CT) results are important in the differential diagnosis and making a final diagnosis. Increased colonic mucosal thickness observed on CT can be a sign of colon pathologies. It has been reported that the lesions revealed by a colonoscopy were $35.7 \%$ tumoral and $13.9 \%$ benign in these patients. ${ }^{[52,53]}$ In our study, 33 (45\%) patients were hospitalized for further evaluation of SPTI. The mean age was $66.48 \pm 13.83$ years, and they were in the risk group. Symptoms and findings of $A M B O$, such as non-discharge of gas or stool, vomiting, air-fluid levels observed on plain radiography, and obstruction signs seen on an oral-intravenous contrast abdominal CT were among the reasons for suspicion of a tumoral ileus. Patients for whom a tumoral ileus was excluded by colonoscopy were admitted to a follow-up program and discharged.

$\mathrm{PI}$ and ACPO were the non-mechanical types of bowel obstruction, and the differential diagnosis is important when considering treatment.

PI or adynamic ileus is defined as a non-mechanical reason for a decrease in peristalsis that affects intestinal contents. The most common type of $\mathrm{Pl}$ is postoperative ileus, which occurs particularly after abdominal surgery. Prolonged surgery and some mediators have been described as important causes of postoperative ileus. Additionally, critical illness, metabolic instability, neurological disorders, and more may be other causes of PI. Supportive treatment, such as cessation of oral intake, fluid and electrolyte replacement, chewing gum, and antibiotics are the basic elements of treatment for PI. Cisapride, neostigmine, and peripheral opiate antagonists are some of the drugs used to treat PI. ${ }^{[54]}$ In our study, PI was found in $1.9 \%$ of the AMBO group. The cause of PI was metabolic in all cases and the most common disorder was chronic renal failure, seen in 6 patients, I of whom died (mortality rate: $7.1 \%)$.

ACPO is described as non-mechanical or non-inflammatory acute dilatation of a partial segment or the total colon and rectum. Pelvic surgery, trauma, orthopedic surgery, and acute cardiac events are the most common reasons for ACPO. Conservative treatment includes nasogastric, and/or rectal decompression, and fluid and electrolyte replacement. Neostigmine, cisapride, gastrografin, and polyethylene glycol can be used as pharmacologic treatment. Colonoscopic decompression and surgery (resection or ostomy) can be performed when conservative or pharmacological treatment is ineffective or in complicated cases. The mortality rate has been reported to be $14 \%$ to $30 \%$ in non-operated patients and $30 \%$ to $50 \%$ in patients who undergo surgery. ${ }^{[55]}$ Our data indicated that the incidence of ACPO was $1.6 \%$ in the overall $\mathrm{AMBO}$ group. Concomitant neurological disorders were found in 6 patients, cardiac disorders in 9 patients, and psychiatric disorders in I patient. In all, 58.3\% were treated conservatively with neostigmine and enema. An ostomy was performed in $25 \%(n=w 3)$ and resection was performed in $16.7 \%(n=2)$. The mortality rate was $25 \%(n=3)$ : I patient died due to aspiration, and 2 patients died after surgery.

Our algorithm for a diagnostic and therapeutic approach to AMBO is provided in Fig I.

In conclusion, AMBO remains important as it is the reason for $9.2 \%$ of all hospitalization to the emergency surgery department. Adhesions are still the most common cause of $\mathrm{AMBO}$, and the incidence has increased. Conservative management of adhesions increases with the experience of the emergency department team. Strategies to prevent adhesions are important and the first responsibility in this regard falls on surgeons with respect to selecting a minimally invasive surgical intervention and minimizing scar tissue. Tumors are the second most common cause of AMBO now that the incidence of hernias has been reduced. Tumors must usually be managed with surgical resection to provide passage, and the mortality rate is higher in this group. Now that screening for colorectal cancers is becoming more routine for patients $>50$ years of age, it will be diagnosed before obstruction of the intestinal passage more often. The incidence of inguinal or femoral hernia has decreased due to elective surgery; however, the number of incisional hernia cases has increased. The incidence of peritoneal carcinomatosis has also grown, and it is as frequent as hernia as an etiology of AMBO. Rare etiological factors must also be kept in mind in the differential diagnoses of $\mathrm{AMBO}, \mathrm{PI}$, and $\mathrm{ACPO}$.

Conflict of interest: None declared.

\section{REFERENCES}

1. Cappell MS, Batke M. Mechanical obstruction of the small bowel and colon. Med Clin North Am 2008;92:575-97.

2. Welch JP. Chap 3, General considerations and mortality. In: Welch JP, editor. Bowel obstruction. Philadelphia, PA: Saunders; 1990. p. 59-95.

3. Markogiannakis H, Messaris E, Dardamanis D, Pararas N, Tzertzemelis D, Giannopoulos P, et al. Acute mechanical bowel obstruction: clinical 
presentation, etiology, management and outcome. World J Gastroenterol 2007;13:432-7.

4. McEntee G, Pender D, Mulvin D, McCullough M, Naeeder S, Farah S, et al. Current spectrum of intestinal obstruction. Br J Surg 1987;74:976-80.

5. Akcakaya A, Sahin M, Coskun A, Demiray S. Comparison of mechanical bowel obstruction cases of intra-abdominal tumor and non-tumoral origin. World J Surg 2006;30:1295-9.

6. Halis N, Söğüt Ö, Güloğlu C, Özgönül A, Gökdemir MT, Durgun HM. Factors Associated with morbidity and mortality in patients with mechanical bowel obstruction. JAEM 2012:1-5.

7. Uludağ M, Akgün İ, Yetkin G, Kebudi A, İşgör A, Şener A. Factors affecting morbidity and mortality in mechanical intestinal obstruction. Ulus Travma Acil Cerrahi Derg 2004;10:177-84.

8. Pędziwiatr M, Budzyński P, Stanek M, Matłok M, Major P, Wierdak M, et al. Mechanical Bowel Obstruction-Changes in Aetiology over the Past 145 Years: A Single Centre Retrospective Cohort Study. Acta Chir Belg 2015;115:397-403.

9. Ojo EO, Ihezue CH, Sule AZ, Ismaila OB, Dauda AM, Adejumo AA. Aetiology, Clinical Pattern And Outcome of Adult Intestinal Obstruction in Jos, North Central Nigeria. Afr J Med Med Sci 2014;43(Suppl 1):29-36

10. Drożdż W, Budzyński P. Change in mechanical bowel obstruction demographic and etiological patterns during the past century: observations from one health care institution. Arch Surg 2012;147:175-80.

11. Jackson PG, Raiji MT. Evaluation and management of intestinal obstruction. Am Fam Physician 2011;83:159-65.

12. Soressa U, Mamo A, Hiko D, Fentahun N. Prevalence, causes and management outcome of intestinal obstruction in Adama Hospital, Ethiopia. BMC Surg 2016;16:38.

13. Doumi EBA, Mohammed MI. Acute Intestinal Obstruction in El Obeid Hospital, Western Sudan. Sudan Journal of Medical Sciences 2008;3:191-6.

14. Kebudi A, İşgör A, Kaya A, Yetkin G. Acute Mechanical Intestinal Obstruction. Ulus Travma Acil Cerrahi Derg 1995;1: 110-2.

15. Kaya B, Uçtum Y, Kutaniş R. Mekanik barsak tıkanıklığı tanısı ile opere edilen 68 olgunun etyolojik ve klinik bulguları: Tek merkezli retrospektif analiz. Turk J Surg 2010;26:3-7.

16. Karabulut M, Gönenç M, İslim F, Kalaycı MU, Kapan S, Turhan AN, et al. Akut mekanik intestinal obstrüksiyon: Bir eğitim ve araştırma hastanesi'nin 5 yıllık deneyiminin sonuçları. Turk J Surg 2011;27:10-4.

17. Füzün M, Kaymak E, Harmancioğlu O, Astarcioğlu K. Principal causes of mechanical bowel obstruction in surgically treated adults in western Turkey. Br J Surg 1991;78:202-3.

18. Çalışkan YK. Ten years ago, what was the main etiology of intestinal obstructions? Historical perspective: A retrospective cohort study. J Surg Med 2017;1:21-3.

19. Ellis $H$. The clinical significance of adhesions: focus on intestinal obstruc tion. Eur J Surg Suppl 1997;5-9.

20. Menzies D, Ellis H. Intestinal obstruction from adhesions--how big is the problem? Ann R Coll Surg Engl 1990;72:60-3.

21. Parker MC, Wilson MS, Menzies D, Sunderland G, Clark DN, Knight AD, et al; Surgical and Clinical Adhesions Research (SCAR) Group. The SCAR-3 study: 5-year adhesion-related readmission risk following lower abdominal surgical procedures. Colorectal Dis 2005;7:551-8.

22. Menzies D. Postoperative adhesions: their treatment and relevance in clinical practice. Ann R Coll Surg Engl 1993;75:147-53.

23. ten Broek RP, Issa Y, van Santbrink EJ, Bouvy ND, Kruitwagen RF, Jeekel $\mathrm{J}$, et al. Burden of adhesions in abdominal and pelvic surgery: systematic review and met-analysis. BMJ 2013;347:f5588.

24. Barmparas G, Branco BC, Schnüriger B, Lam L, Inaba K, Demetriades
D. The incidence and risk factors of post-laparotomy adhesive small bowel obstruction. J Gastrointest Surg 2010;14:1619-28.

25. Fevang BT, Jensen D, Svanes K, Viste A. Early operation or conservative management of patients with small bowel obstruction? Eur J Surg 2002;168:475-81.

26. Köstenbauer J, Truskett PG. Current management of adhesive small bowel obstruction. ANZ J Surg 2018;88:1117-22.

27. Zielinski MD, Bannon MP. Current management of small bowel obstruction. Adv Surg 2011;45:1-29.

28. Ten Broek RPG, Krielen P, Di Saverio S, Coccolini F, Biffl WL, Ansaloni $\mathrm{L}$, et al. Bologna guidelines for diagnosis and management of adhesive small bowel obstruction (ASBO): 2017 update of the evidence-based guidelines from the world society of emergency surgery ASBO working group. World J Emerg Surg 2018;13:24.

29. Matsushima K, Sabour A, Park C, Strumwasser A, Inaba K, Demetriades D. Management of adhesive small bowel obstruction: A distinct paradigm shift in the United States. J Trauma Acute Care Surg 2019;86:38391.

30. Hajibandeh S, Hajibandeh S, Panda N, Khan RMA, Bandyopadhyay SK, Dalmia $S$, et al. Operative versus non-operative management of adhesive small bowel obstruction: A systematic review and meta-analysis. Int J Surg 2017;45:58-66.

31. Ripamonti CI, Easson AM, Gerdes H. Management of malignant bowel obstruction. Eur J Cancer 2008;44:1105-15.

32. Lynch B, Sarazine J. A guide to understanding malignant bowel obstruction. Int J Palliat Nurs 2006;12:164-6, 168-71.

33. Turan M, Karadayi K, Duman M, Ozer H, Arici S, Yildirir C, et al. Small bowel tumors in emergency surgery. Ulus Travma Acil Cerrahi Derg 2010;16:327-33.

34. Biondo S, Parés D, Frago R, Martí-Ragué J, Kreisler E, De Oca J, et al. Large bowel obstruction: predictive factors for postoperative mortality. Dis Colon Rectum 2004;47:1889-97.

35. Pisano M, Zorcolo L, Merli C, Cimbanassi S, Poiasina E, Ceresoli M, et al. 2017 WSES guidelines on colon and rectal cancer emergencies: obstruction and perforation. World J Emerg Surg 2018;13:36.

36. Dolan EA. Malignant bowel obstruction: a review of current treatment strategies. Am J Hosp Palliat Care 2011;28:576-82.

37. Winner M, Mooney SJ, Hershman DL, Feingold DL, Allendorf JD, Wright JD, et al. Incidence and predictors of bowel obstruction in elderly patients with stage IV colon cancer: a population-based cohort study. JAMA Surg 2013;148:715-22.

38. Hayden GE, Sprouse KL. Bowel obstruction and hernia. Emerg Med Clin North Am 2011;29:319-45, ix.

39. Baratti D, Kusamura S, Guaglio M, Deraco M. Peritoneal metastases: challenges for the surgeon. Minerva Chir 2015;70:195-215.

40. Sadeghi B, Arvieux C, Glehen O, Beaujard AC, Rivoire M, Baulieux J, et al. Peritoneal carcinomatosis from non-gynecologic malignancies: results of the EVOCAPE 1 multicentric prospective study. Cancer 2000;88:358-63.

41. Shariat-Madar B, Jayakrishnan TT, Gamblin TC, Turaga KK. Surgical management of bowel obstruction in patients with peritoneal carcinomatosis. J Surg Oncol 2014;110:666-9.

42. Marrero F, Qadeer MA, Lashner BA. Severe complications of inflammatory bowel disease. Med Clin North Am 2008;92:671-86, ix.

43. Berg DF, Bahadursingh AM, Kaminski DL, Longo WE. Acute surgical emergencies in inflammatory bowel disease. Am J Surg 2002;184:45-51.

44. Perrot L, Fohlen A, Alves A, Lubrano J. J Visc Surg 2016;153:183-92. Management of the colonic volvulus in 2016.

45. Halabi WJ, Jafari MD, Kang CY, Nguyen VQ, Carmichael JC, Mills S, et al. Colonic volvulus in the United States: trends, outcomes, and predictors of mortality. Ann Surg 2014;259:293-301.

46. Gürleyik G, Kotan C, Dulundu E, Oztürk E, Sönmez R, Sağlam 
A. Clinical differences between surgically treated patients with large bowel obstruction in the cities of Van and Istanbul. Ulus Travma Derg 2002;8:38-42. [Article in Turkish]

47. Ho TW, Koh DC. Small-bowel obstruction secondary to bezoar impaction: a diagnostic dilemma. World J Surg 2007;31:1072-8; discussion 1079-80.

48. Wang PY, Wang X, Zhang L, Li HF, Chen L, Wang X, et al. Bezoarinduced small bowel obstruction: Clinical characteristics and diagnostic value of multi-slice spiral computed tomography. World J Gastroenterol 2015;21:9774-84.

49. Potz BA, Miner TJ. Surgical palliation of gastric outlet obstruction in advanced malignancy. World J Gastrointest Surg 2016;8:545-55.

50. Alvarez JA, Baldonedo RF, Bear IG, Otero J, Pire G, Alvarez P, et al. Presentation, management and outcome of acute sigmoid diverticulitis requiring hospitalization. Dig Surg 2007;24:471-6.

51. Marwah S, Singla P, Marwah N, Gupta S, Singh VP. Ileal stricture following Meckel's diverticulitis: a rare cause of intestinal obstruction. Clin J Gastroenterol 2016;9:118-23.

52. Read TE, Kodner IJ. Colorectal cancer: risk factors and recommendations for early detection. Am Fam Physician 1999;59:3083-92.

53. Chandrapalan S, Tahir F, Kimani P, Sinha R, Arasaradnam R. Systematic review and meta-analysis: does colonic mural thickening on CT correlate with endoscopic findings at colonoscopy? Frontline Gastroenterol 2018;9:278-84.

54. Batke M, Cappell MS. Adynamic ileus and acute colonic pseudo-obstruction. Med Clin North Am 2008;92:649-70, ix.

55. Pereira P, Djeudji F, Leduc P, Fanget F, Barth X. Ogilvie's syndrome-acute colonic pseudo-obstruction. J Visc Surg 2015;152:99-105.

\section{ORIJINAL ÇALIŞMA - ÖZET}

\section{Mekanik bağırsak tıkanıklığının etiyoloji, yönetimi ve sağkalımı: Türkiye'deki bir eğitim ve araştırma hastanesinin beş yıllık sonuçları \\ Dr. Dursun Özgür Karakaş, Dr. Metin Yeşiltaş, Dr. Berk Gökçek, Dr. Seracettin Eğin, Dr. Semih Hot}

Okmeydanı Eğitim ve Araştırma Hastanesi, Genel Cerrahi Kliniği, İstanbul

AMAÇ: Akut mekanik bağırsak tıkanıklığı (AMBT) acil servisler için halen ciddi bir cerrahi problemdir. AMBT'nin etiyoloji, yönetimi ve sağ kalımı açısından değerlendirmeyi amaçlamaktayız.

GEREÇ VE YÖNTEM: Ocak 2014 ile Aralık 2018 tarihleri arasında bağırsak tıkanıklığı için yatııılmış hastalar geriye dönük incelendi. Yaş, cinsiyet, etiyoloji, yönetim ve sağ kalım AMBT açısından geriye dönük değerlendirildi. Adezyonlar, tümörler, herniler ve peritoneal karsinomatoza daha detaylı değerlendirildi.

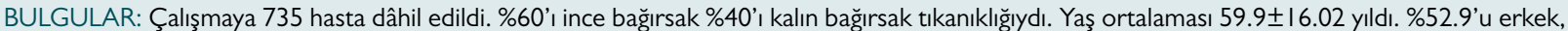
\%47. I'i kadındı. AMBT'nin en sık nedeni adezyonlar, tümörler ve hernilerdi (sırasıyla, \%43.3, \%26.2 ve \%6). İnce bağırsak için en sık neden adezyon (\%69.3), kalın bağırsaklar için ise tümörlerdi (\%6।.6). AMBT'nin en sık yönetimi konservatif yaklaşımdı (\%53.2), cerrahi palyasyon \%24.9 ve rezeksiyon \%2।.9 oranında uygulanmıştı. Konservatif yaklaşım en sık adezyonlarda (\%76.7), cerrahi palyasyon peritoneal karsinomatozada (\%65.7), ve rezeksiyon ise volvulusta (\%6।.9) uygulanmıştı. Mortalite oranı \%8.6 bulundu. Adezyon için kolorektal cerrahi (\%5।.4), tümör için splenik fleksura distal (\%7।.3) yerleşimli kolorektal kanserler (\%93.8) ve herniler için ise sıklıkla gastrointestinal cerrahi (\%57.I) sonrası gelişen insizyonel herni (\%47.7) en sık nedenlerdi.

TARTIŞMA: Adezyon, tümör ve herniler AMBT'nin sırasıyla en sık nedenleridir. En sık yönetim şekli konservatif yaklaşımdır ve çoğunlukla adezyonlar için uygulanır. Femoral ve inguinal herni sıklığı azalırken insizyonel herni sıklığı artmakta, peritoneal karsinomatoza son yıllarda herni kadar sık gözlenmektedir.

Anahtar sözcükler: Adezyon; akut kolonik psödo obstrüksiyon; bağırsak tıkanıklı̆ı; fitık; paralitik ileus; tümör.

Ulus Travma Acil Cerrahi Derg 2019;25(3):268-280 doi: 10.14744/tites.2019.44834 